\title{
ConTratos InTERnaCIONAIS E CONSUMIDORES NAS AMÉRICAS E no Mercosul: \\ ANÁlise da PROPOSTA BRASILEIRA PARA UMA CONVENÇ̃̃o \\ INTERAMERICANA NA CIDIP VII
}

\section{Nadia de Araujo*}

\section{INTRODUÇÃO}

Vai longe o tempo em que o interesse pelo Direito Internacional Privado era reduzido, os negócios intemacionais dificeis e a movimentação pelo mundo demorada. $O$ alcance desta mudança se revela no tema das aulas proferidas no XXXIII Curso de Direito Internacional, promovido pela OEA no Rio de Janeiro, em julho de 2006: os aspectos relativos ao direito internacional privado nos contratos intemacionais envolvendo consumidores, que hoje são do dia-a-dia de todos e há poucos anos eram totalmente desconhecidos.

Hoje o estudo da contratação internacional não se limita às relações entre operadores profissionais, pois os contratos internacionais com os consumidores já representam $25 \%$ do total global de transações. A distinção entre os contratos chamados B2B (business to businesss) e os B2C (business to consumers) adquiriu relevância no plano internacional e influenciou as regras de Diretto Internacional Privado de vários páses.

Essa mudança ocorreu com o barateamento dos custos das viagens internacionais e maiores facilidades de transportes, propiciando grande incremento do turismo. O cidadão comum se viu envolvido em relações transnacionais antes só acessíveis aos comerciantes. Os avanços tecnológicos também aumentaram as transações eletrônicas pela Internet, permitundo ao consumidor estabelecer uma relação contratual de caráter internacional sem sair de casa. ${ }^{1}$

\footnotetext{
* Professora de Direito Internacional Privado, PUC-Rio, Doutora em Direito Internacional, USP, Procuradora de Justiça do Estado do Rio de Janejio. A auto ra agradece a amiga Claudia Lima Marques, especialista em direito do consurudor e em clireito intemacional privado, pelo incentivo e troca de idéas solure o tenua deste estudo, para o qual contribuit com seus textos, e fontes doutrinarias e jurisprudenciais. Tambén agradiece à Daniela Trejos Vargas, Professora de DIPr, PUC.Rio, pela leinara e sugestöes; à mestre Daniela Jacques, pela leirura sugestões bibliográficas, e revisão do texto; e a bolsista do PIBIC Pedro Cavalcante, pela revisăo e orgasizaça da bibliografua.

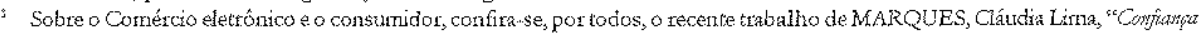

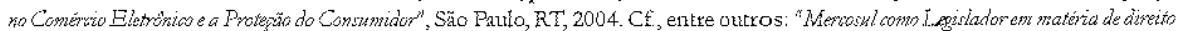

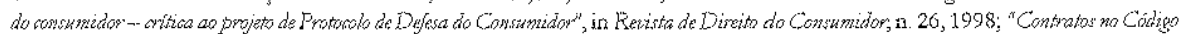
de Defesa do Consumatar", 4h. ed., São Paulo, RT, 2002, especialmente parte I, capítulo 2.5; "A Proteção do Consumictor: aspectos

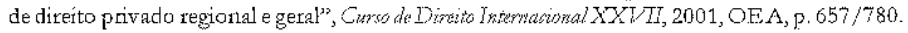


Em ambas as hipóteses criam-se situações multiconectadas em que os consumidores não estão en pé de igualdade com os fornecedores do serviço. ${ }^{2}$

Os contratos intemacionais envolvendo consumidores são cada vez mais freqüentes e se utilizam de contratos de adesão impressos. ${ }^{3}$ No entanto, ha sua maioria, esses contratos têm pequeno valor individual, apesar de somarem em volume para a economia de um pais ou de um fornecedor, o que os torna um negócio expressivo. Esta característica - o baxixo valor econômico da transação -, inviabiliza o acesso à justiça. A lide fica reprimida, pois o consumidor não tem condições de assumit os gastos do processo, seja para reclamar ou para procurar novamente o fornecedor, ou ainda para fazer valer sua garantia.

Essa é uma das grandes diferenças de perspectiva entre os negócios internacionais realizados entre comerciantes e aqueles que envolvem consumidores. São necessánias regras diferenciadas para essas transaçôes internacionais. As normas já utilizadas no comércio internacional asseguram a confiança entre as partes e a continuidade dos negócios. A tônica da proteção é para quem realiza a venda, quem envia mercadorias a um desconhecido. No consumo internacional esta lógica se inverte, pois o comprador é a parte mais fraca, deixa-se levar pela propaganda, não considerando os riscos legais do negócio, mormente no plano intemacional.

Para o Direito Internacional Privado, os contratos internacionais de consumo despertam duas questões que precisam de regulamentação específica: a da lei aplicável e a da competência internacional. A regulamentação intema de cada Estado é ineficiente para cuidar da matéria e necessita ser tratada no plano internacional, através de uma convenção multilateral.

Segundo Ciaudia Lima Marques, "há uma especificidade do comércio entre fornecedor e consumidor no plano internacionat: por um lado, a fraglidacte do consumidor em mazáo do marketing agressivo, sencio atraído ou por métodos como telemarkerng: teleshopping, vendas emocionais de trme-sharing para uristas) ou por preços reduzidos (descontos, techlyão nos tributos, envio granito ete), pelo senso de aventura (jogos, apostas, prêraios), ou por sua própria igno ráncia quanto h̀s difrculdades nas transsaçóes transinacionais (parco conhecinento da lingua para entendex a ofetta ou a publicida de, mito da qualidade superior dos produtos importados, produtos-novidade, desconhecicios em príses emergentes, pela falta de conselhos juridicos ou de um departamento jurídico para a neģociaçăo, confiança que a marca terá serviços pós-venda en seu país etc). O consumo intenacional ainda possu uma úlima especificidade, qqe lhe é comun con os serviços en geral sua re-execuçäo, en caso de frastiaçăo das expectativas do contratante consumidor é bastante dificultosa. Em caso de turismo, reeditar algo, una excursăo, dias de férias em praia poluida, recuperaro conforto de um hotel em país distante e assin por diante, é tarefa quase imrpossivel a a resposta será apenas econômica, com as perdas e danos respectivas. Em materia de contratos à distância, a eventaralidade da perda de tempo, da perda de ma chance e de acontecerem danos morais anexos à má-execuçăo do contrabo internacional

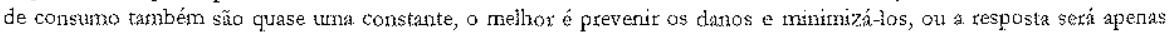

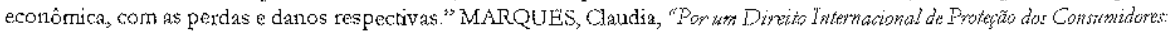

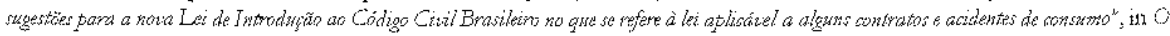

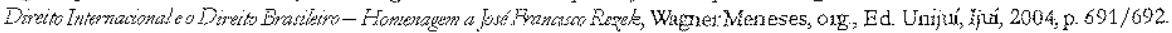

${ }^{3}$ Cf. FRESNERO DE AGUIRE, Cecilia, "Las Chusulas abusiyas y la chasula de jurisdiccion en los contratos internacionales de

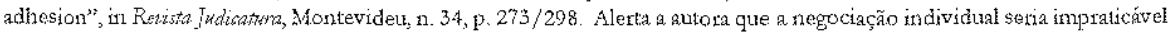
por xäöes econônicas, razão por que esses contratos cumprem a tarefn de regular as relaçöes das efrapresas com seus clientes a un custo baixo e tempo adequado. Adverte, porém que esses contratos têm caractéx́s ṫcas próptias e precisa de regulanentaçấo diversa dos demenas. 
Na Europa, essa uniformidade já foi alcançada por meio de convençôes específicas e reg:as da Comunidade Européia." Nas Améticas, defende-se neste trabalho a adoção de uma Convenção específica sobre a Lei aplicável aos contratos envolvendo os consumidores. Com essa nova convenção, o sistema interamericano ficaria completo, pois a Convenção Interamericana sobre o dircito aplicável aos contratos internacionats (México, 1994) não cuida expressamente desses contratos internacionais.

Uma vez aprovada, a Convenção Interamericana scria utilizada também no Mercosul, promovendo a unifomização das regras no bloco e complementando o direito intemo dos páses. Essa convenção trataria da proteção do consumidor no âmbito do Mercosul, uma preocupação já externada na Declaração dos Direitos Fundamentais dos Consumidores do Mercosul. ${ }^{5}$

Neste trabalho analisaremos a primeira questão, a partir da interessante proposição da Professora Claudia Lima Marques para a realização de uma Convenção Interamericana sobre a lei aplicável aos contratos internacionais envolvendo os consumidores. ${ }^{\circ} \mathrm{Com}$ a sua aprovação os consumidores terão o mesmo nivel adequado de proteção dos comerciantes. A realização de una convenção sobre o tema trará segurança a essas transações intemacionats, contribuindo para o aumento do fluxo comercial, e beneficiando, globalmente, todos os páses envolvidos.

A CIDIP VII já teve seu temátio aprovado pela Resolução n. 2065 da Assembléia Geral, e os temas definidos foram: proteção do consumidor e garantias mobiliárias. No primeiro, os tópicos são: lei aplić́vel, jurisdição e restituição monetária, que poderão ter a forma de convenção ou lei modelo. Foi institứdo um foro de discussão na internet e nos dias 2 e 3 de dezembro de 2006, realizar-se-á uma reunião de especialistas, em Porto Alegre, para discutir os projetos já apresentados.

- Além de várias diretivas dirétamente aplicáveis aos contratos intemacionais com os consumidores, está vigente a Convençäo sobre a lei aplicável aos contratos intetnacionais, também conhecida como Convenção de Roma. No entanto, há uma discussăo em andamento sobre a conversăo da Convenção de Roma para um Regularnetro, e o projeto contempla inúmeras modificaçôes na questão dos contuatos com os consumidores, chanado de Rorna I.

" Declaraçio feita em Flocianópolis pelos presidentes dos Estados-partes, en 15 de dezembto de 2000, disponível exn whw marcosur.otg.ty.

"MARQUES, Claudia Lina, "A proteça do consunidow: aspectos de direito privado regional e geral", in XXY/M Cursa de Derecho Internacionai2000, Secretaria General, OEA, Washington, 2001, p. 657/780. 


\section{CARACTERÍSTICAS DO DIPR PARA OS CONTRATOS INTERNACIONAIS ENVOLVENDO OS CONSUMIDORES NAS AMÉRICAS, NO MERCOSUL E EM CONVENÇÕES INTERNACIONAIS}

\section{I.a Regras internas de DIPr para determinar a lei aplicável aos contratos internacionais envolvendo os consumidores nas Américas e no Mercosul}

A necessidade de proteger o consumidor no âmbito intemacional através de normas especificas de DIPr foi apontada pela doutrina estrangeira desde a década de $1970 .{ }^{7} \mathrm{Na}$ Europa, a aplicação de soluções particulares a esses contratos deu-se em consonância com a tendência geral de assegurar uma proteção especial às partes mais fracas da relação contratual. ${ }^{B}$ A idéia foi retirar estes contratos do sistema de lei aplicánel x ordem pública, para criar uma regra de conexão especial. Observa-se essa solução no art. $5^{\circ}$. sobre a lei aplicável aos contratos envolvendo consumidores da Convenção de Roma sobre a lei aplicável às obrigações internacionais.

A primerra legislação especifica nas Américas foi a norte-ame ricana, seguida da do Canadá e da do México. ${ }^{9}$ No Cone Sul, o Brasil teve papel precursor na proteção aos seus consumidores ao incluir: esse direito no rol das garantias e direitos fundamentais na Constituição de 1988 (art. $5^{\circ}$. XXXII). A determinação constitucional resultou, em seguida, na elaboração do Código de Defesa do Consumidor. Essa legislação mudou o ambiente contratual e o tratamento desses litígios pela justiça brasileira. ${ }^{10}$

Sob sua influência os demais páses-membros do Mercosul implantaram leis especializadas. $O$ avanço da integração regional com o Mercosul traz essa problemática para o dia-a-dia dos páses-membros com o aumento dos negócios e do fluxo de turistas da região. " Mas só no final da década de 1990 foram criadas leis especiais para o consumidor.

Fazendo uma rápida descrição da legislação dos países-membros temos: na Argentina, a Lei de Defesa do Consumidor, ${ }^{12}$ de 1993 , logo após a lei brasileira, e muito posterior ao

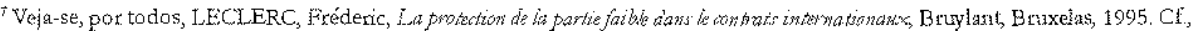

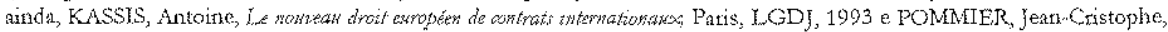

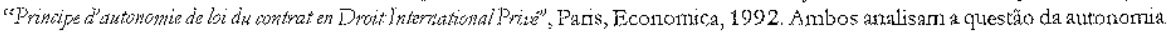
da vontzde e suas linitaçoes fiterte aos contratos inirenzacionais com os consumidores.

"RIGAUX, Fratzçois, "Droithinternational Privê", come II, Bruxelas, Maison Larcier, 1993.P. 567 e segrantes

"Cl. MARQUES, "A proteçäo do consurnidor..., OEA",667 e seguintes.

iv Lel 8.078/90. Há uma vasta litentura sobre o CDC no Brasil. CE, pox todos, MARQUES, Claudia Lima, "Confratos no Código de Defosa do Consumidor" $4^{3}$. edição, Säo Paulo, RT, 2002, que contén unna analise dos contratos internacionais de consumo. Cfainda, para um estudo mais completo sobre as dálusulas abusivas, CARPENA, Heloísa, Abuso do Direito nos matratos de ronsumo, Rio de Janeiro, Renovar, 2001.

${ }^{1 i} \mathrm{O}$ Mercostrl é un processo de integração que tem una baxid coercitividade juxidica de sens instinuentos, ante a ausencia de caráter suprasiaciona de qualquer de seus órgăos. De acordo com a sistemática em vigor, todia a regulamentaçäo do Mercasul, feita na maior parte das vezes através de Protocolos, precisa ser intemalizada pelo sistema dássico do Direito Internacional Público en cada Estado nembro. Nesse contexto, o terua de defesa do consumidor foi alvo de iniciativas de harmonização que, até a presente daca, ainda não estāo sendo ap̧icadas, por não terem sido internalizadas

- Lei $24.249 / 93$.
} 
Código Civil; no Paraguai, a lei de defesa do consumidor é de $1998,{ }_{1.3}^{13}$ posterior ao Código Civil de 1986; no Uruguai, a lei de defesa do consumidor é de $1999,{ }^{14}$ também posterior ao Código Civil de 1868, modificado em 1994.

Todaria, nenhum dos paises-membros possui regras de DIPr especiais para os consumidores na contratação intemacional e não houve nenhuma iniciativa significativa no âmbito do Mercosul com resultado concreto. ${ }^{15}$ No plano interno, à exceção do Brasil cujo DIPr está regulado pela Lei de Introdução ao Código Civil (LICC), com a conexão do país da celebração, o dos demais paises está regulado pelos Tratados de Montevidéu, com algumas diferenças nas regras aplicáveis aos contratos internacionais. Tais regras são rígidas, com características do século XIX, e contrárias à possibilidade de as partes escolherem livremente a lei aplicável. Argentina, Uruguai e Paraguaí utilizam a regra de inspiração savigniana da lei do local da execução e, apenas subsidiariamente, a do local da celebração. As soluções dos Tratados de 1889-90 foram mantidas pela reforma elaborada em 1939-40, que rechaçou a possibilidade da utilização da autonomia da vontade. ${ }^{16}$ Destaca-se, neste contexto, a Argentina, que passou a aceitar a autonomia da vontade mediante construção jurisprudencial. ${ }^{57}$ Por isso, é urgente uma regulamentação de caráter intemacional, para tratar da questão da lei aplicável às relações dos consumidores no plano regional através de uma conferência especialızada da OEA, e da jurisdição internacional, que é a proposta de Claudia Lima Matques. ${ }^{18}$ No plano

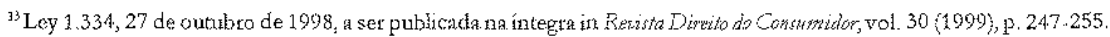

${ }^{14}$ Ley 17.189 , de 20 de seternbro de 1999 , publicada na integra in Renista Direito ho Consmidor, vol. 33 (2000), p. $262-270$.

${ }^{15}$ O Mercosul já atingin um bom grau de unifomizçio de nomas juxídicas, que envolvem primordialnente aspectos de pzocesso civil internacional, mas de lei aplicével também. Cf. Regras do Protocolo de Las Lenas sobre Cooperaçño enssistência jurisdicional en matéra civil, comercial, trabalhista e administrativa; Protocolo de assistência jurídica en matéria penal; Protocolo de Medidas Cautelares; Protocolo de Brenos Aires sobxe Jurisdição iaternacional em matéxia contualual (que exclui expressatmente os contratos com o consumidor de seu âmbito de aplicação); Protocolo de Sáo Luis em matéria de Responsabilidade Civil ennergente de acidentes de tránsito entre os Estados-Partes, todos enrigor no Brasil e ros demais Estados.

${ }^{16}$ CF OPPERTI-BADAN, Didier, e FRESNERO DE AGUIRRE, Cecilia, "Contratos Comentates Intomactonales", Montevidéu, FCU, 1997

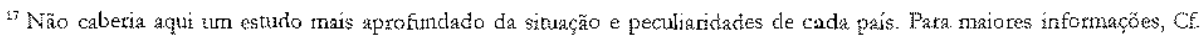
ARAUJO, Nadia, Contrates Intemaiconais, 3a. ed., Rio de Janeiro, Renovar, 2004, p.77 e seguintes e ARROYO, Diego P. (coord) Devecho Internacional Privado de los Estotios do Mescosur, Buenos Aires, Zavalia, 2003.

${ }^{13}$ Para esta última, no plano regional foi elaborado o Protocolo de Santa Maria sobre jurisdição intemacional de telaçôes de. consurxo, mas ainda rão vigente Dec. CMC n. 10/96. Para o texto, ver ARAUJO, Nadia et allii, Códrgo do Mermsml, Rio de Janeiro, Renovar, 1998 , p. 159 e seguintes. Ver, ao finaì do texto, uma resolução sobre os principais conceitos sobre consurnidor, muto

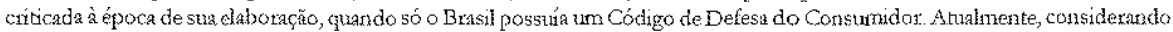
que os demais paises possuem leis intemas sobre o assunto, taivez pudesse ser desvinculado do texto do Protocolo de Santa Maria. Apenas o Paraguai encerrou o procedimento de incorporação. Nos denais países, sur incorporaçã⿰o ainda não ocorreu. E isso não é novidade, pois raros säo os páses que posstaem em sell ordenanento intemo no nias de DIPr específicas para o consumidor. Estados Unidos e Canadí são dois exemplos de países com essa pteocupação que possuem uormas para a ptoteção dos consumidores. CF MARQUES, "A proteçño do consumidor..., OEA", P. 675 e seguintes: "Quunto ao DiPr. do Quebec, positivado no Código Civil de 1991, interessante observar sua atualização metodológica, porque prevê várias no tmas abertas (Art. 3076), o conhecimento de leis irmperativas de outro estado (Art. 3079), uma ordem pública estrita pela. incompatibilidade do resultado ptático da aplicação da lei estrangeira (Axt. 3081) e umra cláustrla escapatóna geral (Art. 3082). Assim como posstui uma regra específica para os contratos de consumo (Art. 3117), perminindo a autonomia de vontade, mas considexando obrigatónas as nomas imperativas do foro, en iclenticas circunstancias que o Art. 5 da Convençăo de Roma e indicardo, na falta de escolina, a lei da residência do consumido cono aplicável. Por exempla, a lei de proteção ao consumidor dat Venezuela é de 1995. A nova lè venezuelana de Direito Intemacional Privaco é posterior e data de 1998, mas, em seus 64 artigos, nada menciona especificamente sobre proteção do consumidor, apesar de várias vezes nencionar os "principios generales del Dexecho Comercial Intenacional". Mesmo assim, a nova lei venezuelana traz normas atualizadas sobre a 
intemacional, o consumidor continua a ser o "protagonista olvidado" nas inúmeras tentativas de harmonização legislativa. Para dirimir a situação, a autora sugeriu a elaboração de uma Convenção Interamericana sobre a lei aplicável aos contratos de consumo, com uma sugestão de redação, ${ }^{20}$ que foi afinal apresentada pelo Brasil para a CIDIP VII.

Aliás, além de uma convenção intemacional, Claudia Lima Marques também defende, no plano interno brasileiro, a reforma da atual Lei de Introdução ao Código Civil, para incluir regras de conexão mais flexiveis e adaptadas à tutela da parte vulnerável. No seu entender, houve uma falência das conexões "neutras" e rígidas, mais adaptáveis ao relacionamento entre iguais ou pelo menos entre profissionais. Essas regras são inadequadas para o consumidor, pois ainda está vigente o artigo $9^{\circ}$. da Lei de Introdução ao Código Civil, que determina como noma geral a lei do local da celebração do contrato como a lei aplicável. A possibilidade ou não de as partes escolherem a lei aplicável ao contrato intenacional ainda é cercada de polêmica na doutrina e não tem sido aceita pela jurisprudência pátria. ${ }^{22}$

Conclui-se que não há, atualmente, em nenhum dos países do Mercosul, regras de DIPr destacando ou diferenciando os contratos intemacionais com os consumidores dos demais, sendo aplicável o regime geral.

aplicaçũo das nomas imperativas nacionais ( Art. 10), sobre a conexão equitetiva para o caso concreto (art. 7) e, especialmente, uma nowna te en fayor vítina em caso de acidentes ou atos ilicitos, o que pode bexaficiar os consumidores (Aut. 32)."

v Expressão de Michel Arrighi, apwd MARQUES, Chudia Lima, Curo da OE A, p. 696.

- Segundo a autora, ficaram tamosos os trabalhos de ZWWEIGERT, NEUHAUS e LANDO, sugerindo o primeiro que o DIPr. inclússe valozes sociais $e_{2}$ o segundo, que se abandonasse a autonomia de vontade nos contratos entre contratanles fracos e Fortes, como os de consumo e o terceiro, pragrnaticamente, que passasse o DIPr. a escolher como conexão o domićlio do contratante mais fraco. Cf, ainda, a dissertação de mestrado do Programa de Pós-Graduaçăo em Direito da UFRGS, JACQUES,

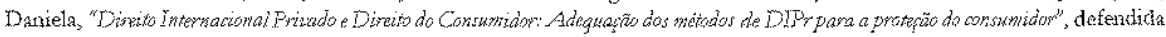
em janeiro de 2004, e no prelo, na RT, na Biblioteca de Direito do Consurridor. Cópia com a autora.

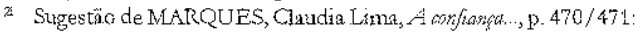

Art. 9 bis. Proteção contratal dos consumidores] Os contratos e as transações enavolvendo consumilores, especiamente os contratados à distância, por meios eletrônicos, de teleconuunicnçöes ou por telefone, estando o consundor en seu país de donicílio, serão regidos pela lei deste países ou pela lei mais favo tável ao consumidor, escolinda entre as partes, se lei do lugar da celebração do contrato, lei do lug̣ar da execução do contrato, da prestação caracteríscica ou lei do donucílio on sede do fornecedor de produlos e serviços.

Parágrafo $1^{\circ}$. Aos contratos celebrados pelo consumidor estando fora de seu pais de doniclio será anlicada a lei escolinia pelas partes, dertre a lei do lugar da celebração do contrato, a lei do lugar da exectçấo e a lei do donichlio do consumidor.

parágrato $2^{\circ}$. En todos os casos, aplicat-se-ño necessariantente as normas do país do foro que tenhan caráter imperativo, na proteça do consunidor.

Parágrafo $3^{\circ}$. Terido sido a contratação precedida de qualquer atividade negocial, de maketing, do fornecedor ou de seus representantes, em especial de envio de publiciclade, correspondencia, e-mails, premios, convites, manuterçâa de llikal ou representantes e denais arvidades voltadas para o fomecimento de produtos e serviços e atraçăo de clientela no pás de domichio do consumidor, aplicar-se-ño, necessarianente, as normas imperativas deste país, na proteção do consumidor, cumulativamente àquelas do foro è la aplićável ao contrato ou relaçä́ de consumo.

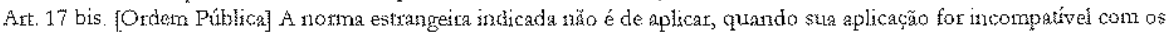
direitos fundamentais, a destacar-se a incompatibilidade com a dignidade da pessoat humana e os direitos do consumidor.

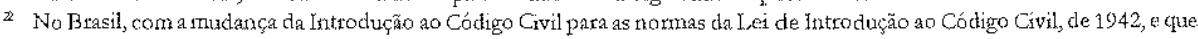
até hoje está exz vigor, nascel una nova discussão na doutrina, sobte a exclusão ou não do primcipio, em face da surpressăo

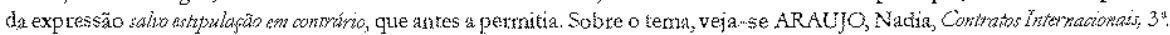
ec., Rio de faneiro, Renovar, 2004. Com a mesma letura da LICC, ce, MARQUES, Cláudia Lima, "Confianga no Comirno Elemómio Ea Protefäo do Consmnidar", São Pnulo, RT, 2004, p. 446, para quem as no mas do art. $9^{\circ}$. são obrigatórias e excluem a autonomia da vontade, nos contratos intemacionais em geral, e nos de consuno, em particular. Em sentido contrítio, Cf DOLINGET, Jacob, "O Direito intemacional e sua aplicaçăo pelo direito brasileiro: atualidades e perspectivas do Direito Internacional 


\section{I.b Regras de DIPr de origem convencional}

No campo da uniformização da codificação de Direito Intemacional Privado de orgem intemacional, à exceção das regras da União Européia, o consumidor não teve melhor sorte. As iniciativas que cuidaram da regulamentação da contratação intemacional excepcionaram os contratos com o consumidor ou nada falaram a respeito. Nesse sentido, a Convenção da Compra e Venda Intemacional, da UNCITRAL, ${ }^{23}$ e os Princípios sobre os Contratos Comerciais Internacionais, do UNIDROIT.24 Ambos os documentos cuidam somente dos contratos intemacionais entre comerciantes e excluem os consumidores do seu âmbito de aplicação. Do mesmo modo, a Conferencia da Haia de Direito Internacional Privado tratou da Compra e Venda Internacional, em 1955 e 1986, mas suas convenções não possuem regras especificas para o consumidor. ${ }^{25}$

No âmbito intemacional, a União Européia possui diretivas e regulamentos específicas para a questão. $O$ Tratado de Amsterdã definiu a proteção ao consumidor como um direito fundamental do bloco, e as regras a respeito representam um vade-mécum de Proteção ao Consumidor. Também no projeto de Constituição Européia, a proteção ao consumidor tem grande importância nos objetivos que a União quer atingir. ${ }^{26}$

Privado", in ODineito Internabionale o Direito Brasileir, org. Wagner Meneses, Ijui, Ed. Unijui, 2004, p.878 e seguintes. Para nan exemplo da jurisprudência, veju-se AI. 1.111.650., jo. Tribunal de Alçada de São Paulo, jul gado em 24 de setembro de 2002. Ementa: "1) Arbitragem. Constinłcionalidade. Contrato de agência contendo cláusula que impöe a resolução dos conflitos no juizo atbitral, segundo o dreito francés. Validade. Inteligência do art. $2^{\circ}$. da Lei n $9307 / 96$. Kacidència do princípio da autonomia da youtade 2) Inépcia da inicial. Ilegitirnidade passiva. Inocorrência. Inicial çue preenche os requisitos legrais. Alegação de existêsicia de contrato vexbıl de representação comercial. Cabimento. Recurso parcialmente provido." No corpo do acórdão taz-se a distinção entre a aplicaçầo do art. $9^{\circ}$ e, conseq̨ientemente, pela possibilidade da escolna da lei az̧enas quando horrer cláusula arbitral, em virtude da disposiçào expressa do art. $2^{\circ}$. da lei de arbitragenn.

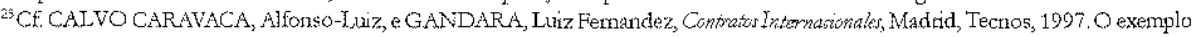
inais importante são as normas uniformizadoras da Convenção da ONU solure Compra e Venda de Mercadarias de 1980 , conhecida como Convenção de Viena de 1980, çae em seu Axt. 2, a e Axt. 5, procuram evitar a aplicaçáo destas nomnas do comércio internacional as contratos com consumidores-leigos. O Att. $2^{\circ}$ da Convença de Viena de 1980 dispóe: "Esta convençãon não se aplica às vendas; a) ce mercado xias açuiridas para uso pessoal, familiar ou doméstico, salvo se o vendedor, antes ou no momento da celebração do contrato, não soubesse nem devesse saber que as mercadorias exam adquiridas para tal usa". E no âmbito do Conéxcio eletrônico a lei modelo da LNCrRRAL (que efetivamente se dedica ao comércio intenacional) versando sobre conércio eletrobico expressamente infoma năbo afastar as numas tatelares e parece querer excluir os contratos de consumo através de meios informáticos de seu campo de aplicação com o texto: "Art. 1. Ámbito dé aplicación - La presente Ley* será aplicable a todo tipo de información en forma de mesaje de datos utilizada en el contexto de actividades comerciales. *La presente ley no deroga ninguna noma juídica ciestinada a la protección del consumidor." No

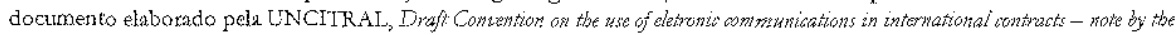
Secretariat, A/CN.9/577/Add.1. 17/11/04, p. 9, há urna referência específica da inaplicabiliclade da furum convenç̧̃̃o aos contratos eletronicos coin os contumidotes.

${ }^{24}$ No Brasil, há poucos trabalhos específicos sobre os Principios do Unidroit, destacando-se, SOUZA yr., Lauro da Gama, "Os

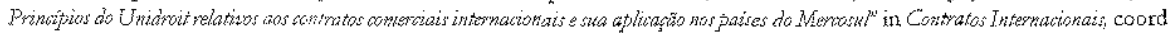
Joăo Grandino Rodas, 3" ed., Sżo Paulo, R'T, 2002, p. 427, CASEL1, Pano Borba; "Utilizaçăo no Brasil dos Prircípios

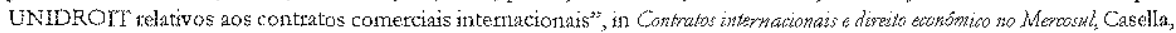
Paulo Borba (Coord.); Sino Paulo, 1996, p.98-99.

¿ Convenção sobre a lei aplicável às vendas de caráter internacional de objetos móveis corpóreos, 1955, que nada dizia; e Convençăo solure a lei aplicável aos contraios de venda intemacional de mercadorias, 1986, que excepcionava os contratos com os consumidores no at: 2 , cen termos similares ao adotado pela Convençäo sobre Compra e Venda Internacional, da YNCTTRAL.

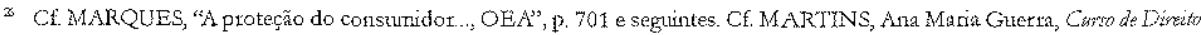
Constituciomal da Uniäo Eurpéia, Coimbra, Almedina, 2004. A autora, comentando as nodificações do 'Tralado de Amsterdã ras 
Por isso, começa-se a análise das iniciativas regionais pela a Convenção Européia sobre a lei aplicável às obrigações intemacionats, de Roma, $1980,{ }^{27}$ para em seguida tratar-se da Convenção Interamericana sobre o direito aplicável aos contratos intemacionais, México 1994, da OEA ${ }^{2.8}$ Ambas adotaram o princípio da autonomia da vontade como regra geral para a escolha da lei aplicável aos contratos intemacionais, seguidas de regras subsidiánas para quando não houver escolha - o critério dos vínculos mais es treitos.

Saliente-se que a previsão da utilização da autonomia da vontade é um dos problemas que afligem a relação consumidor $x$ fornecedor no plano intemacional, e foi tratado na Convenção do México, ${ }^{20}$ e na Convenção de Roma. A possibilidade ampla de escolher a lei aplicável é mais adaptada às relações de partes em igualdade de condiçôes, mas inadequada se utilizada para as relações envolvendo os consumidores,${ }^{30}$ cujos contratos são de adesão. Léclerc alerta que esses contratos $(B 2 C$ ), embora com elementos internacionais, conservam sua natureza de contratos de adesão, e, conseqüentemente, sua estrutura de desigualdade entre as partes. ${ }^{31}$ No entanto, isso não significa retirar a possibilidade de escolher a lei dos consumidores, mas sim a criação de normas especiais em que se preserve sua escolha e não se abra mão de um nível de proteção especial, por serem eles a parte mais fraca da relação jurídica.

Enquanto na Europa a autonomia da vontade foi drasticamente limitada através do art. 5'. da Convenção de Roma, ${ }^{32}$ a Convenção do México ignorou a necessidade dessa limitação para esses contratos.

políticas e ações comunitáxas relacionadas ao cidadão, esclarece que os consumidores passaraxin a sex encarados não apenas do ponto de vista econónico, mas como ưn conjunto. Segundo o novo att. 153 do Tratado, a Conunidade contriburá para

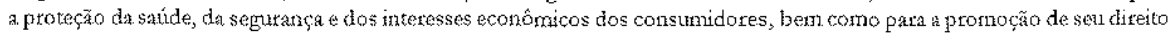
à intoromação, à efucação e à organização para a defesa de sens interesses (p. 100)

2 Sobre a Convenção de Roma, veja-se ARAUJO, Nadia, Contratos Intemacionais, $3^{3}$. Ed., Rjo de Janerro, Renovar, 2004. CE, ainda, NORTH, Peter, Priate International Lan problent in common lan jurisdictions, London, Martirns Nijhoff, 1992. Esclatece o autor que, enbora haja um artigo especial de protę̧̃̃o aos consumidores na Convenção de Roma (art. $5^{\circ}$ ), que dernonstra a preocupaçăo de dax esta proteçäo através das nomas de conflito, estas foram redigidas de forma miazto limitada e serão aplicadas a poucos contratos, na sua opintĩo. A noma do artigo 5 estabelece que a escollia da lei aplicável (autonomia da vontade) está limitada, nos contratos de consumo, e não pode prejudicar a aplicação das nomas de caráter imperativo da

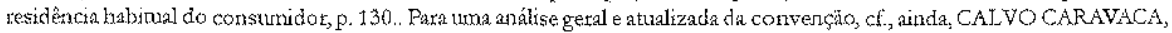
Alfonso Luiz, e GONZALEZ, Javier Carrascosa, (diretores) Derecho Tntrnaciosal Prizado, vol. II, 5a. ed, Granada, Ed. Comares, 2004.

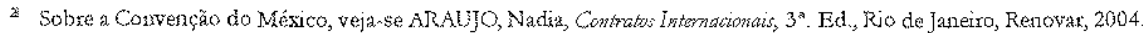

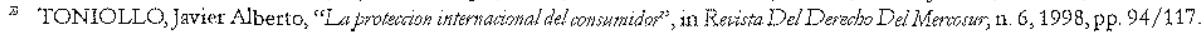
$O$ autor alerta para a necessidade de que a tradicional regra neutra de conexăo seja ajustada por valotes substantivos no contexto de proteger a parte mais fraca, p.99. Nesse sentido, em razão da debilida de das no mas argentinas especializadas de DIPr, ublizame o princípio da arden pública com o fro de proteger o consumidor quandio necessário.

3) A esse respeito CF MAYER, Pierre, "La protection de la partie faible en Drcit International Prive", in L a tomatection de la partie faible dins les raptont rontractuels, LGD J, Pans, 1996, p. 513/552. No estudo, o autor relata inímeros exemplos de regras européias que protegen o consurnidor e se apjlicarn nos casos intermacionais, ao invés da regra de conexão clíssica.

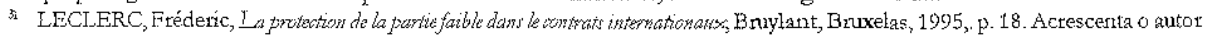
que a síução só se complica, pois, ka passagen do contrato do ânbito intemo paxa o internacional, se acrescentam-se ao poderio econônico da parte mais forte as barreiras lingiústicas, a ignotância da lei estrangeita e outras especificiçades (como, por exemplo, a diliculdade de litigar em foro estrangeiro).

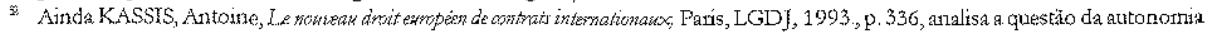
da vontacle $x$ contratos intemacionais com o consumidor, para concluir que a Convenção năo a excluiu, mas apenas a limitou pata garantir que a escolha preserve o nivel de proteção adequiado cque deve texo consumidor, em face de disposições imperativas 
A Convenção de Roma dá um tratamento diferenciado aos contratos internacionais com os consumidores, no art. $5^{\circ} .2^{33}$

Para esses contratos os princípios gerais da convenção - autonomia da vontade e vínculos mais estreitos na ausência de escolha - não são utilizados. Há uma regra de conflito especial e rígida para essa classe de contratos, definida no n. 1. do artigo. ${ }^{34}$

Essa regra especial da Convenção não se aplica a todos os contratos com o consumidor. mas somente aos que cumpram certas condições materiais e espaciais. As condições materiais dizem respeito ao objeto do contrato (bens móveis ou serviços) e ao sujeito (que não é profissional). Também entram no âmbito de aplicação o financiamento a esses contratos e os pacotes turísticos. Com relação aos requisitos de ordem espacial, a idéia é proteger o consumidor passivo, que recebeu uma oferta ou publicidade em sua residência habitual, ou em feiras e seminários. ${ }^{35}$ Para os consumidores ativos, a proteção se estende somente aos pacotes turísticos. E embora na época em que a convenção foi feita ainda não houvesse contratos pela internet, estes estão abrangidos pela norma do art. 5.2. No entanto, estão excluídos da proteção da Convenção inúmeros contratos, como os de transporte, aquele no qual o consumidor está em posição ativa, ou quando a transação for relativa a imóvel.

Atualmente há uma proposta de mudança na Convenção de Roma, que a tomaria um Regulamento, chamado de Roma I. A proposta foi apresentada pela Comissão Européia e modifica vários aspectos da Convenção. Com relação aos consumidores, adota uma regra de conexão fixa, a lei da residência habitual do consumidor. Se houver escolha, esta deverá seguir alguns critérios fixos. ${ }^{36}$

Aa le interna Acredita que no caso concreto é preciso analisar todas as leis envolvidas, pororue aquela escolhicta pode ser mais protetiva do que regrim imperativa do foro, e ainda, que a lei escollida pelas partes pode regular setores do contrato não cobertos pela lei aplicável do foro. 0 art. 5.2 é uma regra de conflito alternativa e que só será usada depois de comparados os conteridos das duas leis envolvidas no conflito.

3) Art. 5 - Contratos celebrados por consurnidores

1. Opresente artigo aplica-se aos conantos gque temhára por objeto o fornecinento de bens móveis conyóreos ou de serviços a uma pessoa, o "consunidor", para una finalidace que pode considexa-se estranha à sua atividade profissional, ben como aos contratos destinados ao firianciamento desse fornecinento.

2. Nâo obstante o disposto no art. 3 liberdade de escolher a lei], a escollia pelas partes da lei aplicável não pode ter como consequêencia privar o consuruidor da proteção que lhe garantern as disposiçôes imperativas da lei do país em que tenha a sua residência habitual: a) se a celebração do contuto tiver sido precedida, nesse paises, de uma proposta que lhe foi especinlmente dirigida ou de anúncio publicitário e se o consurudor tivex executado nesse país todos os atos necessários à celebração do contrato ou; b) se a outra parte ou o respectivo representante tiver recebido o pedido do consumidor nesse pás ou; c) se o contrato consistim numa venda de mercadorias e o consumidor se viver deslocado desse país a lum outro país e aí tiver feito o pedido, desde que a viagem tenha sido organizada pelo verdedo: com o objetivo de incitar o consumidor a comprat:

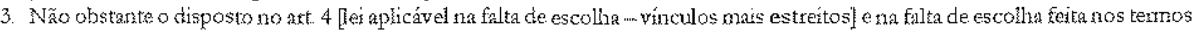
do att. $3^{\circ}$, esses contratos se zão vegulados pela lei do pais em que o consunidor tiver sua residêncin labinal, se se verificarem as circunstâncias referidas no n. $2^{\circ}$, do presente attigo.

4. O presente artigo nâo se uplica: a) ao contrato de transporte; b) ao contrato de prestaçăo de serviços quando os serviços devidos ao consumidor devam ser prestados exclusivamente num pás diferente daqutele err que este terr a sua tesidência habitual.

5. En derrogaç̆o do disposto no n. 4, o presente artigo aplica se ao contrato que estabeleça por um preço global, prestaçoes combinadas de transporte e alojamento.

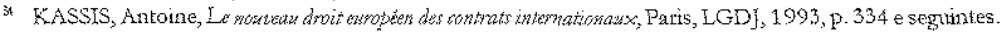

3 CAIVO CARAVACA, Alfonso-Iurz, e GONZALEZ, Javier Cartascosa, (Ciretores) Derecho Imternacional Prizado, vol. II, $5^{\circ}$. ed., Granada, Ed. Comares, 2004, p. 577 e seguintes.

3. Proposta de modificaçäo da Convenção de Roma, Koma I, COM (2005)650 linal 
Já nas Américas, a Convenção do México não menciona os contratos de consumo, nem sua exclusão de seu âmbito de aplicação, ${ }^{37}$ contendo somente uma proteção indireta, quando prevê a aplicação das notmas de caráter imperativo. ${ }^{38}$ Pode-se adotar uma interpretação extensiva do art. $3^{\circ}$ - que amplia o campo de aplicação da Convenção às novas modalidades de contratação surgidas do desenvolvimento do comércio internacional. Poderia ser considetada como inclusiva dos contratos com os consumidores no sistema da Convenção, pois esta é uma categoria nova que cresce a cada dia nas trocas intemacionais.

Esse ponto não passou despercebido aos que analisaram a Convenção do México. Toniollo defende sua adoção somente se houver reserva de sua exclusão para o âmbito dos contratos com partes mais fracas. ${ }^{39}$ Também por essa razão Claudia Lima Marques propõe uma outra Convenção Interamericana que cuide da lei aplić́vel aos consumidores, juntandose às regras da Convenção do México. No seu entender, só quando ambas as convenções estiverem atuantes, ter-se-á uma regulamentação mais completa das relações contratuais internacionais, separando-se as chamadas relações $B 2 B$ das $B 2 C C^{40}$

\section{A PROPOSTA DE CONVENÇÃO INTERAMERICANA SOBRE ALGUNS CONTRATOS E TRANSAÇÕ̃ES ENVOLVENDO OS CONSUMIDORES, CIDIP VII}

\section{II.a O Trabalho das CIDIrs e o atual estágio dos preparativos para a CIDIP VII}

As Conferências Interamericanas Especializadas de Direito Intetnacional Privado, conhecidas como CIDIPs, foram responsáveis pela elaboração e aprovação de diversas convenções interamericanas sobre quase todos os aspectos do DIPt. Esse trabalho de criação

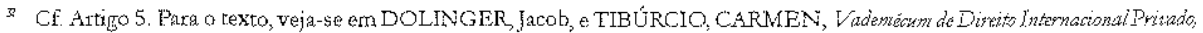
$2^{a}$. ed., Rio de Janeiro, Renovar, p. 266/269. Pata o texto da Convetzção de Roma, na mesma obra, p. 474 e seguintes.

3 Art. 1 - Não obstante o disposto nos artigos anteriones, aplicar-se-ão necessariamente as disposições do dituto do foro

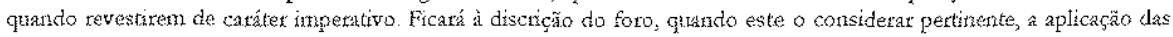
disposiçóes imperativas do direito de outro Esłado com o qual o contrato mantiver vínculos estreitos.

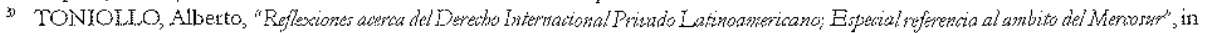

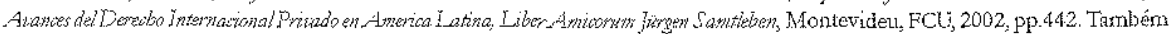
no mesino sentido, cf. OPERT TI BADAN, Didier e FRISNERO DE AGUIRRE, Cecilia, Contrato Comrertaies Iricernatianales, Montevideu, FCU, 1997

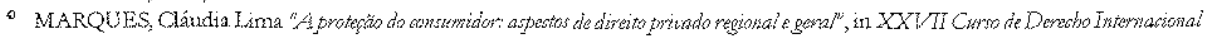

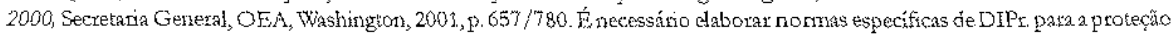
dos consumidores leigos ou não profissionais, pois as conexöes hoje existentes para regular o comércio internacionaj todas têm como base o equilíbrio estrutrial de forças ou de interesses profissionais entre os agentes (ambos profxssionais) envolvidos, como conexöes da autonomia da vontade (escolha da lei que tegetá o contzato pelas partes, no contrato ou após), o local da execução (geralmente o local de execuç̃o da prestação caracteristica, sempre prestada pelo profissional em caso de conztrato de consumo intenacional), ou do local de conclusão do contrato (conectanto o contrato con a orden juridica do país do ofertinte, em contratos à distancia, sempre tarxbém o of fetrante).

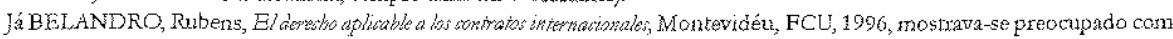
a falta de zegulamentaçẫo na Convenç̧ão Interamericana sobre os contratos exu duas partes: no plano subjetivo, com as partes contratualmente ranis fracas e no plano objetivo, com a falta de definição das situaçöes relativas ro conarato de adesão. Assinala serem esses contratos os mais comms e conipueitos de nossa época e que não pecaria por excesso a Convenção do México de excepcioná-los de seu canpo de aplicaçăo. (p. 135). Este equilibtio estmitural inexiste nos contratos intemacionais conclúdos com consumidotes leigos. Assim, se a autonomia de vontade das partes é hoje considerada o mais importante elenento de conexăo no conzércio intentacional encontra ela um Iimite no que se reféte às velaçóes de consumo. 
de uma nomativa uniforme aas Américas têm grande importância para o Dipr, em geral, e para o Mercosul, em especial, pois os países integrantes do bloco são partícipes ativos no processo. Várias delas estão em vigor nos quatro países, promovendo a uniformização das regras de DIPr no bloco. ${ }^{41}$ Todavia, no campo dos contratos internacionais, a Convenção do México sobre o diteito aplicável aos contratos internacionais teve pouca aceitação (só dois países a ratificaram) e não regulou os contratos con consumidores. ${ }^{42}$

A Comissão Jurídica Interamericana, instada pela Assembléia Geral da OEA, ao estudar novos temas para as Conferências Especializadas, recomendou o dos consumidores e do comércio eletrônico, por sua pertinência e importância ${ }^{43}$ No relatóno, apontou-se a necessidade de regulamentação para promover o incremento dessa área comercial. Diego Fernández Arroyo, em trabalho realizado a convite da OEA, também apontou para a incompletude da Convenção do México, mormente no tema dos contratos com os consumidores. ${ }^{44}$ Em seguida, a Assembléxa Geral da OEA recomendou a realização da CIDIP VII. ${ }^{4.5}$ Vátios países - como o Brasil, Uruguai, México e Canadá-, já se manifestaram. a favor da proteção dos consumidores para a próxima reunião. ${ }^{46}$

Em 2004, a Assembléia Geval chamou os paises a participarem da montagem da agenda e os órgãos competentes a apresentar estudos para viabilizar a realização da Conferência. ${ }^{47} \mathrm{Na}$ sessão de 2005 , foi aprovada a resolução 2065 , que definiu a agenda da CIDIP VII, incluindo o tema de consumidor logo no item $1 .{ }^{4},{ }^{48}$

A proposta de uma Convenção Interamericana sobre a lei aplicável aos contratos internacionais de consumo é um dos prováveis tópicos da agenda da próxima CIDIP. Sua realização é imprescindivel para se completaro sistema, que está incomple to com a Convenção

\footnotetext{
4: Para maiores informaçōes sobre a sua vigência, veja-se en wwwossorg para uma análise detallakda de cada uma delas e o

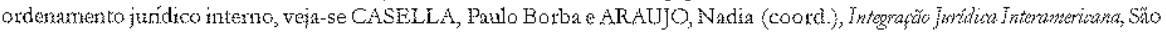
Paulo, L'Tr, 1998.

Até hoje só foi intermalizada na Verlezuela e no México.

B Veja-se documento Cidip VIT and Beyoná, elaborado por Carlos Mamel Yasquez e Joño Grandiro Rodas, membros da Comissão

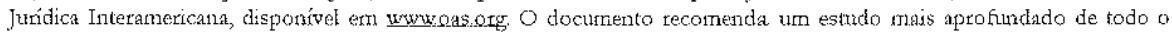
sistema CIDIP, por um pequeno grupo de especialistas, em conjunto com a Comissão, para deterninar o seu fuatro, pois é preocupante o baixo número de ratificaçōes das convencôoes mais recentes em comparação com as mais artigas. [A Convenção do México é um exemplo dessa constataçăo]. Ayonta, ainda, o problema da duplicação de esforços, através de iniciativas de culno regronal $x$ inciativas de cuno global. Na análise dos tópicos da próxima CIDIP, mencionam comércio eletrónico e consuruidor como un dos tópicos mais sequisitados pelos páses, e sua justaposiçăo.

4 Veja-se documento The Present and the future of Cidis ARROYO, Diego P. Femandez, in wwwonsorg.

f. Res. $A G$. 1923 (XXXXII-0/03), adokada na sessão de 10/06/03.

* As propostas são diferenciadas. A proposta de uma convenç̃o sobre a le aplicável é brasileira, baseacta no texto da Prof. Claudia Lima Marques. O Unuruá apresentou un tópico sobre comércio eletrônico con consumidores. Adiciona, ainda, a Declaração de Córdoba, em çue divexsos jursistas se manifestam en favor do sistema Cidip e falarn da necessidade de regular os aspectos relativos aos contratos internacionás com os consumidores. Já o Canadá quer o tópico do comércio eletrônico apenas no aspecto relativo à jurisdição intexnacional. O México unbém quer una convenzção sobre proteção do consumidox. já os Estados Unidos e ourtos paises preferem a mo dalidade de leis-modelo para tratar de remas relacionados a inves timentos e tegistro de tranjaçöes comerciais eletrônicas.

4. Res. Ag 2033 (XXXIV-0/04), adotada na sessâo de 8/6/04.

4) OEA/SerG/CP/CAPJ-2239/05 rev.1, 18/2/2005. Ver Ag. /Res. 2065 (XXXV.0/05, aprovadana 4ª Sessão plenária, em 7 de junho de 2005.
} 
do México. Espera-se seja adotada a vertente em uso na União Européia, que possui regras especificas para os contratos interaacionais envolvendo os consumidores.

A regulamentação especial para os consumidores de ambas as questões - lei aplicável e jurisdição intemacional - é essencial para garantir proteção adequada nas obrigações transnacionais e o acesso à justiça. Só com essas regras se poderá garantir a proteção dos direitos fundamentais desse grupo, essencial ao bom desenvolvimento do comércio intexnacional.

Um dos pontos que causa mais polêmica na regulamentação dos contratos intemacionais é o princípio da autonomia das partes em escolher a lei aplicável, e os limites a essa autonomia quando houver interesses dos consumidores. Enquanto na seara intemacional do $B 2 B$, a faculdade de escollher a lei é desejável, nos contratos $B 2 C$ dever-se-ia impor limites precisos para evitar que o consumidor não tivesse, afinal, escolha alguma, sendo-lhe imposta alei do fornecedor do bem ou serviço. ${ }^{49}$

As soluções mais modernas para os consumidores não excluem totalmente a autonomia da vontade nos contratos em que eles forem partes. Essa eleição deve ser permitida, mas com certos limites, para garantir um nível adequado de proteção, pois, como parte mais fraca, o consumidor precisa de normas de DIPr diferenciadas. ${ }^{50}$

Ao final de 2006, os trabalhos preparativos para a CIDIP VII estão em pleno andamento. O Brasil apresentou uma proposta de convenção, de autoria de Cláudia Lima Marques, que será analisada no próximo item. Além disso, Canadá e Estados Unidos também apresentaram propostas sobre o tema dos consumidores. O projeto dos Estados Unidos é sobre mecanismos de restituição monetátia para os consumidores e tem o formato de leimodelo. O Canadá também utilizou o método de lei-modelo para sua proposta sobre jurisdição relacionada ao uso da internet. ${ }^{51} \mathrm{O}$ Uruguai também apresentou uma proposta de convenção com os dois temas: lei aplicável e jurisdição.

\section{II.b A proposta de Claudia Lima Marques para uma Convenção Interamericana de lei aplicável aos contratos internacionais envolvendo os consumidores}

Cláudia Lima Marques respondeu ao convite para dar aulas no Curso de Direito Intemacional da $\mathrm{OEA}$ com a elaboração de uma proposta de convenção ${ }^{52}$ para a agenda da CIDIP VII, posteriormente apresentada pelo Brasil para a OEA. Sua inspiração veio da constatação de que a regulamentação internacional para os contratos internacionais nas

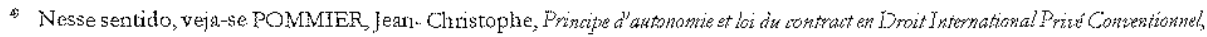
Paris, Economica, 1992, 1) 157. Para ele, a altonomia da vontade com regra de conexão exa uma fonte de opressão da prite

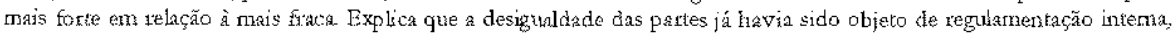
principalmente nos contratos de trabalho e nos contratos com os consumidores, de maneira a atastar a autonornia das partes.

" MARQUES, Claudia Liru, A confianga a., p. 459

s Todos os documentos e propostas poden ser encontrados em wrwoas org 110 setor de assuntos juridicos, diteito internacional privadio.

5 MARQUES, "A protecío do consunidor..., OEA", p. 763/675. Cópia da proposta ao final deste trabalho.
} 
Américas, a Convenção do México, deixou os consumidores sem regras próprias. Essa ausência não se justifica, e sua proposição foi feita a partir dos estudos das regras da Comunidade Européia, tanto a Convenção de Roma como inúmeras diretivas especiais.

A autora reconhece que a doutrina latino-americana vê as regras de proteção do consumidor como normas de ordem pública internacional - permitindo sua exclusão do sistema da Convenção do México pelo disposto 110 art. $11,{ }^{53}$ mas acredita ser este artigo insuficiente para assegurar a proteção necessária ao elo mais fraco da relação contratual. No seu entender, o artigo 11 é um paliativo, dando preferência às normas imperativas da lex fori, inadequadas a essa classe de contratante. ${ }^{54}$ Além disso, deixa dois tipos de consumidores sem qualquer proteção especial: o turista, que sempre compra de forma "intemacional", e o que contrata a distância ou por meio do comércio eletrônico. Não é certo que as normas imperativas ou de ordem pública do país de domicilio do consumidor serão aplicadas em caráter discricionário ${ }^{55}$ pelo juiz do foro competente, geralmente o do fomecedor.

A análise da jurisprudência brasileira demonstra que os juizes tendem a ignorar o caráter internacional da relação jurídica, para aplicar apenas o $\mathrm{CDC}$, como se viu no caso Panasonic. ${ }^{56}$ Essa visão do problema não é exclusiva do direito brasileiro e já foi constatada por Antonio Marques dos Santos, que cita a ocorrência freqüente na Alemanha e em Portugal. ${ }^{57}$

A proposta de Convenção de Claudia Lima Marques é composta de sete artigos. Define o consumidor, estabelece cláusulas sobre a lé aplicável [inclusive regra limitada sobre

${ }^{53}$ Veja-se, por todos, HERNANDEZ-BRETON, IPRAX 1998,384 , comunicando também a entrada em vigot da CID $V$ entre México e Venezuela em 14.1.1997, IPRAX, p. 379.

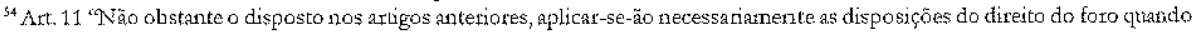
revestirem caráter mperacivo. Ficará à discriçăo do foto, quando este o considerar pertinente, a aplicação das disposições imperativas do direito de outro Estado com o qual o contrato nantiver os viticulos mais estreitos." OEA/Ser.K/XXI.5, CIDIP V/Doc. 46/94, vol. I e II, 1996, p. 29. Sobre o tema das normas de aplicação inediata, veja-se, por todos, MARQUES DOS SANTOS, Antonio, As nomas de aplicafäo innediata no Dineita Internacional Prizado, vol. I e II, Coimbra, Alnedina, 1991

\$ OEA/Ser.K/XXI.5, CIDIPV/Doc. 46/94, vol. I II, 1996, p. 29.

th Resp 63.981 adotada na sessão de 13/08/2001, do Superior Tribunal de Justiça. RSTJ, Brasília, ano 12, n. 137, jan. 2001, p. 387492. Ementa: DRETYO DO CONSUMIDOR. FILMADORA ADQUIRDANO EXTERIOR DEFEITO DAMERCADORLA. RESPONSABILIDADE DA EMPRESA NACIONAL DA MESMA MARCA ("PANASONIC"). ECONOMH GLOBALIZADA. PROPAGANDA. PROTECÃOAO CONSUMIDOR PECULIARIDADES DA ESPÉCIE SIYUACOEES A PONDERAR NOS CASOS CONCRETOS. NUYIDADE DO ACORDAO ESTADUAL REJEITADA, PORQUE SUFICIENTEMEATE FUNDAMENTADO. RECURSO CONFIECIDO E PROVIDO NO MÉRITO, POR MAIORLA. I . Se a economia globalizada não mais tem fronteiras rigidas e estimula e favorece a liv te concorrência, inprescindivel que as leis

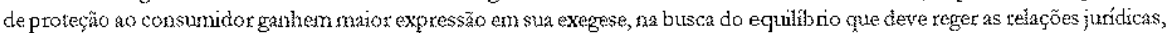
dimensionando-se, inclusive, o fator risco, inerente à competitividade do comércio e dos negócios mercantis, sobretudo quando em escala intemacional, em que presentes empresas poderosas, multinacionais, com filiais em vários príses, sem falar nas verzdas hoje efenados pelo processo recuológico da infomátca e no forte mercado consumitor que representa o nosso Pás. II - O mercado consumiclor, nĩo hí como negar, vê "se hoje "bombardeado" diuturnamente por intensa e hábil propaganda, a irdazir a aquisição de produtos, notadamente os sofisticados de procedência estrangeina, levando em linha de conta diversos fatores, dentre os quais, e com relevo, a respeitabilidade da marca. III - Se empresas nacionais se beneficiam de matcas mundialnente conhecidas, incumbe-Hlhes responder também pelas dếnciencias dos produtos que anunciam e comercializam, aão sendo razoável destrinar-se ao consumidor as consequiências negativas dos negúcios envolvendo objetos defoinosos. IV - Impóe-se, no entanto, nos casos concretos, ponderar as siturções existentes. V - Rejeita-se a nulidade argüida quando sem lastro na lei ou nos autos.

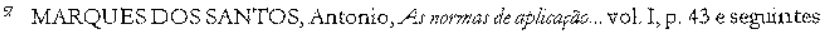


a autonomia da vontade], normas imperativas, e cláusula escapatória (de exceção). Prevê, ainda, uma regra de exclusão de determinados contratos, como seguros, transportes e os da Convenção do México. Além disso, inclui normas especiais para os de viagem e turismo e de multipropriedade.

A definiçã̃o de consumidor do artigo $1^{\circ}$. permite que o texto se harmonize com a Convenção do México, cujo campo de aplicação é muito amplo. Assim, ao individualizaro sujeito-consumidor, com a vigência de ambas as convenções, não haverá dúvida de que o consumidor estará excluído da Convenção do México. As convenções de direito internacional privado não possuem apenas normas conflituais. É comum regularem aspectos de direito material, como definições do sujeito ou objeto em pauta no documento. São as chamadas normas materiais de Dipr. ${ }^{58}$ Essa definição foi inspirada em diversos documentos, especialmente na Convenção de Roma, e nas diversas diretivas européias sobre a matéria.

Ainda no artigo $1^{\circ} \mathrm{d}$ a proposta, o itern 3 estabelece uma série de situações para de finir o consumidor nos casos específicos do consumidot-turista e da multiproptiedade. Caminha no mesmo sentido da Convenção de Roma, que também estabelece presunções para definir o local do contrato, utilizando a teoria da prestação característica. No entanto, a teoria foi expressamente descartada da Convenção do México, que adotou uma posição mais geral em relação aos contratos internacionais. ${ }^{60}$

$O$ art. 1.4 estabelece como guia de interpretação a escolha da norma mais favorável ao consumidor para que não paire dúvidas sobre quem a Convenção quer proteger. É uma notma aberta que segue o princípio da escolha da definição da lei que dê maior proteção. Pode exemplificar-se sua utilização com o exemplo do Brasil, no qual o Código de Defesa do Consumidor - CDC também protege o consumidor pessoa-juridica, enquanto a proposta só inclui o consumidor pessoa fisica. Desta forma, quando a convenção estiver em vigor, poderá utilizar-se, em um caso concreto, o critétio mais favorável.

O art. $2^{\circ}$. cuida da lei aplicável aos contratos a distância, especialmente os eletrônicos. A regra geral é a do domicílio do consumidor. Essa regra se harmoniza com a norma do Mercosul constante no Protocolo de Santa Maria para a jurisdição intemacional, ainda não

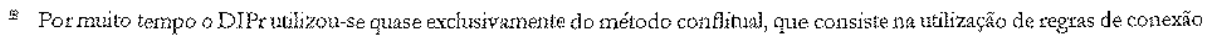

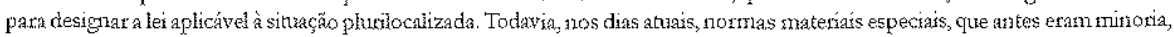
e que responden à pergunta proposta através de uma solução imediata estão sendo muito utłlizadas, especialınente ena convenções intenacionais. Além disso, há urma nova categotia de nomas materiais imperativas Segruado Alfonso Calvo Caravaca, essas normas de direito inteno, por conterem implicitanente um mandako de proteşăo aos casos intenacionaís, também são normas que integram DIPr CF. CALVO CARAVACA, Alfonso Luiz, e GONZALEZ, Javier Carrascosa, (diretores) Demecho Internacional

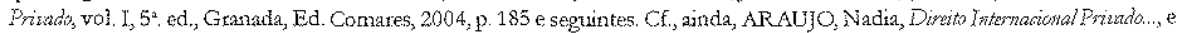

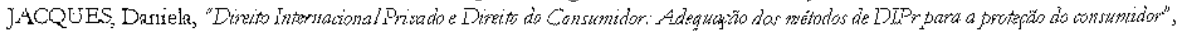
derendida en jarieico de 2004, e no prelo, an RT, na Biblioleca de Direito do Consurnidor. Cópia com a autora.

" Segundo Clauclia Lima Matques, nos Art. 5 da Convenção de Roma de 1980 sobre a lei aplicável a obrigações contratuais, Art. 2,1 Diretiva 85/577/CEE sohre contratos negociados fora do estabelecimento cornercial, Art 2, be c da Diretiva 93/13/CEE sobre cláusuias abusivas nos contratos celebrados com consumidores, Art 2,2 da Diretiva 97/7/CE de 20 de majo de 1997 sobre contratos à distânacia, e Art 1, 2 a da Diretiva 1999/44/CE de 25 de maio de 1999 sobre venda de bens de consurno e garantús.

- Segunio Clandia Lima Marçes, nos art. Art. 2.4 e 4.3 da Diretiva 90/314 sobre viagen combinada e Diretiva Européta $94 / 47 /$ $\mathrm{CE}$ de 26 de outubro de 1994 (Diretiva sobre time-shanitg), e em estućos da coutrina européia. 
em vigor. $O$ domicílio do consumidor deve ser entendido como sua residência habitual, a exemplo do art. 3 do Protocolo de Santa Maria ${ }^{63}$ e da tradição das convenções interamericanas, que sempre usam essa expressão ao invés de domicilto, por ser considerada mais ampla. Como esses contratos são de adesão, podendo ser oriundos de países em que se permite a autonomia da vontade, buscou-se uma solução de compromisso que não eliminasse a possibulidade de escolha da lei. Nesses casos, ante a provável imposição da norma ao consumidor pelo fornecedor, a proposta prevê uma alternativa à da invalidade da cláusula: somente será aceita em três hipóteses: lei do lugar da celebração, lei do lugar da execução, ou lei do domićlio ou sede do fornecedor do produto ou serviço. Todas cuidam de situações em que existe um vínculo real entre o contrato e o local da lei aplicável. Evita-se a possibilidade da escolha de uma lei que não tenha nenhum vínculo com o contrato, mas que foi letta somente por ser mais favorável ao fornecedor. Protege-se o consumidor da escolha alheia, sem eliminar completamente a autonomia da vontade. Esta opção é repetida no item 2, para os contratos celebrados fora do domicilio do consumidor.

O único reparo a esse artigo seria a retirada da hipótese de prestação característica, que nesse caso não se mostra adequada, pois, sem a lista de presunções necessárias à sua compreensão. Mesmo na Convenção de Roma, em que há uma relação das presunções, essa metodologia para encontrar a lei aplicável é muito criticada. Fim marcada diferença, a versão da Convenção do México depois das discussões da Conferência não acatou essa solução, que fazia parte do proje to inicial. Friedrich Juenger, un de seus críticos, acredita que esta é uma solução inadequada porque nem sempre é fácil determinar em contratos complexos qual das diversas ações das partes deve ser considerada como característica da relação contratual. ${ }^{62}$ Além disso, sugetimos a repartição do 2.1, como se vê no anexo, para sua melhor comprcensão.

As demais Convenções existentes para os contratos intemacionais - Roma e México - possuem como regra geral para escolha da lei aplicável a autonomia da vontade. Na sua ausência atua o critério subsidiário dos vínculos mais estreitos. A idéia de que o consumidor está em posição de inferioridade em relação ao fornecedor e tem pouca possibilidade de escolha embasa esta opção pela lei mais favorável, c distingue esse contrato dos demais.

Para o Brasil, a adoção desta convenção significaria um distanciamento da regra do art. $9^{\circ}$. da Lei de Introdução ao Código Civil brasileiro - LICC, que para contratos a distância privilegia o proponente (que nos contratos com os consumidores são os fomecedores). Sua adoção representa grande modificação no atual sistema brasileito, ${ }^{6,3}$ e um avanço para a

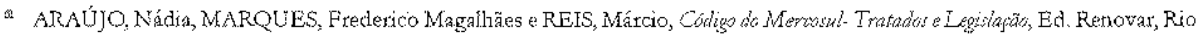
de Janeiro, 1998, p. 161.

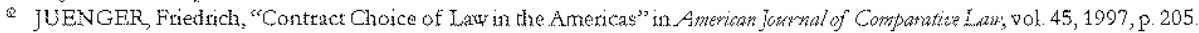
Anda criticando a prestaço caracteristica, entende o autor que esse conceito estabelece un privilégio para os fonecedores de serviços e mercadorias, que seriam a parte característica da relação contratual. (p. 206) Acrecìta ainda que é uma conexão frcticia, arbitrána e de difícił aplicação. In "La Convencion Europea sobre el detecho aplicable a obligaciones contratuales: algunas observaciones criticas deste la perspectiva estaduinidense, in jwotica, n. 14, 1982, p. 201

E Confira, neste trabaitio, nota 15. 
proteção dos consumidores, pois a LICC é da época em que estes ainda não eram tratados como um grupo diferente dos demais na seara contratual.

Desta forma, protege-se o consumidor, evitando-se que a jurisprudência considere sempre o CDC como norma de aplicação imediata, através da possibilidade de utilização da lei mais benéfica. Essa modalidade de norma já é conhecida no Brasil em casos de sucessão internacional com a existência de cônjuge ou flho brasileiro. Quando o de cujus tiver seu domicilio no extenior, e for caso de aplicação da lei estrangeira, o juiz deve analisar qual delas (a brasileira ou a estrangeira) é mais benéfica. Já houve casos de aplicação da lei estrangeira, por ser mais favorável aos brasileiros, seguindo-se a diretriz cons titucional.$^{64}$

Ainda sobre a autonomia da vontade, dir-se-ia que sua inclusão em uma convenção internacional seria na verdade inócua, já que na maioria das vezes o consumidor não tem nenhuma oportunidade de fazer qualquer opção, pois se obriga a um contrato já pronto. Discordamos dessa visão. $\mathrm{Na}$ verdade, a possibilidade de escolla da lei aplicável pode se dar de forma bastante simplificada. Por exemplo, nos contratos realizados na internet, pode haver duas opções, bastando ao consumidor clicar uma delas (tal qual cláusulas do tipo () Aceito () Não aceito, existentes em inúmeros contratos). É evidente que nos contratos com os consumidores não há tempo nem condições de uma efetiva negociação e será necessário encontrar uma fórmula prática e simplificada para viabilizar a possibilidade estabelecida na nova convenção.

Ultrapassada a questão relativa à forma pela qual se dará a opção, pergunła-se porque o fomecedor se preocuparia em dar essas opções. Na verdade, é do interesse do fomecedor, cada vez mais, dar ao consumidor opções que lhe dêem segurança na contratação. É sabido o temor de muitas pessoas em contratar pela internet, especialmente em sites mtemacionais, por conta dos riscos da operação. No Brasil, na contratação interna, proliferam os sites ditos certificadas. Muitos consumidores, ao acessarem sites de busca, que dão os preços e condições de vários sites sobre um mesmo produto, incluem informações sobre a qualictade do serviço prestado por alguns deles. A opção do consumidor não é guiada apenas pelo preço, mas também por esses itens, que atestam a maior segurança da operação, evitando aborrecimentos futuros.

$O$ fornecedor, para convencer o cliente a usar seu site, tem interesse em que este tenha tranqü̈lidade em contratat. Portanto, muito plausivel em uma contratação internacional por meto eletrônico, que gera mais insegurança, que o fornecedor ofereça ao consumidor mais de uma opção de lei aplicável, que inclua, por exemplo, a da sua residência habitual. A mera existência dessa opção, ainda que simplificada, concorrerá para o aumento das transações, e aos poucos, será utilizada em toda a rede, visto que os concorrentes não vão que*er ficar para trás. 
O artigo $3^{\circ}$, que trata das normas de aplicação imediata, inspirou-se na Convenção de Roma e nas regras alemãs. A autora utilizou uma fórmula que permite a utilização da norma imperativa em conjunto com a idéia da procura da lé mais adequada, procurando-se escolher sempre aquela que for mais favorável ao consumidor. Desta forma, o juiz deverá realizar uma operaçẫo complexa: aplicar as normas imperativas do foro em que o consumidor tem domicílio, porque para lá foi dirigida a propaganda, principal item de attação do fornecedor, em conjunto com as da lei aplicável ao contrato. Tudo para cumprir a filosofia da convenção, disposta no artigo 1.4, de procurar o critério da norma mais favorável.

O artigo 4", da cláusula escapatória, merecia ter sua terminologia modificada para cláusula de exceção, ${ }^{65}$ mais próxima da nossa tradição jutidica e utilizada pelo Prof. Erik Jayne. Ainda que a situação prevista no artigo pareça rara e dificil de ocorrer, sua inclusẫo no texto convencional é importante em termos metodológicos por nos aproximar das modernas tendências do Direito Internacional Privado e deixar uma cláusula aberta para o futuro, de modo a garantit melhor a proteção desejada para o consumidor.

A idéia de uma cláusula escapatória (ou de exceção) foi inspirado no artigo 15 da Lei Suiça ${ }^{6}$ que tem sido considerado muito adequado para dar ao sistema conflitual clássico uma souplesse do seu sistema de utilizar a regra de conexão rígida para a lei aplicável, aproximando-se de soluções que levem em conta o caráter material do resultado. Também. evita a utilização da exceção de ordem pública como regra geral para cuidar de todas as soluções indesejávess, mantendo a sisstemática do método conflitual.

A distinção entre cláusula de exceção e ordem pública foi feita por Erik Jayme. ${ }^{67}$ Para ele, essa cláusula não descarta a lei aplicável estrangeira, apenas a modifica, em algumas circunstâncias, ainda utilizando o sistema de conflito de leis. Reconhece, todavia, que embora haja diferença na aplicação de cada uma delas, o resultado pode ser o mesmo. Porém, há casos em que a diferença no resultado aparece, quando a aplicação da cláusula de exceção remeter a uma outra le i estrangeira aplicável. Se na mesma situação fosse utilizada a exceção de ordem pública,o resultado seria a aplicação da lei do foro, quando inaplicável a lei estrangeira.

Alfonso Calvo Caravaca ${ }^{68}$ diz que a utilização da cláusula de exceção só ocorre para evitar uma lei pouco conectada com a situação e cuja solução senia imprevisível para as partes, preferindo-se uma outra, mais próxima (que poderá ainda ser uma lei estrangeira ou a lei do

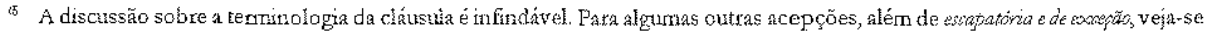
MARQUES DOS SANTOS, As nomas de aplicaçäo.., vol.1, p. 399/400. De notar ainda que há países ema que se faz a dis tinção

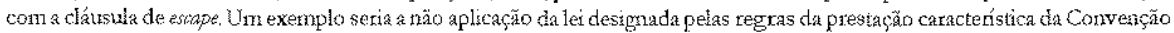
de Rona, porque levariam a uma lei sen vínculos estreitos com o contrato, o que seria contrário a lógica da regra yesal. In, CAIVO CARAVACA, Alfonso-Lurs, e allii, Dereibo Internacional Frizado, vol. 1, 5ै. ed., Granada, 2004, p. 217

“ Art. 15. Cláusula de exceção: “1. O direito designado pela presente lei nã̃o será aplicado, se, excepcionalinente, em xazão das circurstâncias, é manifesto que a causa possui laços thetrues com o direito designado, e que se encontre conectada, de forma mais estreita com outro direito. 2. Essa disposição não é aphićável em caso de eleição do direito aplicável.

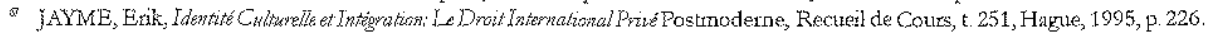

4 CALVO CARAVACA, Alfonso-Luis, e alli, Deremo Internaconal Prizado, vol. I, 57. ed, Granadia, 2004, p. 217. 
foro). Esta cláusula integta-se ao sistema de conflito de leis, existindo apenas para corrigir a ratio da norma de conflito.

A técnica de amenizar o rigor das regras de conexão com cláusulas de exceção foi uma resposta dos parses europeus às críticas ao sistema conflitual clássico, conhecido por seu caráter mecânico e indiferente ao resultado final da escolha da lei aplicável, feita pelos autores americanos, após a conhecida American Rerolution. ${ }^{69}$

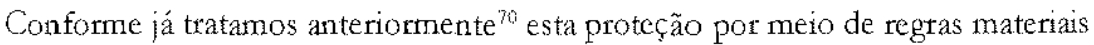
especiais para o consumidor seria uma extensão da noção de direitos humanos aplicados ao consumidor própria do DIPr do terceiro milênio. Está mais próxima de um DIPr que não ignora a solução material a ser atingida pela regra de conexão, e respeita os ditames constitucionais de proteção à dignidade da pessoa humana. Um verdadeiro DIPr de matiz principiológico, que caminha no sentido de uma visão mais aberta em relação à tradicional teoria clássica dos conflitos de leis, na qual a regra de conexão era cega ao seu resultado. Na Europa, essa relação já está imbricada nos casos decididos pela Corte Européia de Direitos Humanos, não havendo, na opinião de Patrick Kinsch, razão pela qual o método do Direito Internacional Privado deva deixar de estar sob a égide dos Direitos Humanos ${ }^{7 !}$

Atualmente, o DIPr se preocupa não só com a segurança jurídica obtida pela certeza do caminho indicado pelas normas de conexão, mas também com sua dimensão social, de chegar com suas escolhas a uma solução mais justa e adequada ao seu papel de respeito à justiça material. Isso só pode ser obtido com novos tipos de regras de conexão, que dêem alternativas ao sistema, ou seja de caráter objetivo, dirigido e não mais neutras em relação aos resultados. Um exemplo é a tegra de conexão que determina a lei aplicável do local da residência habitual do consumidot, a menos que este escolha outro.

Erik Jayme bem analisou a questão ao finalizar seu curso da Haia com a noção de um DIPr pós-modemo: "O DIPr aparece como um sistema que preserva sua estrutura tradicional, mas, ao mesmo tempo, está aberto à realização de valores novos. ${ }^{\text {"72 }}$

Representando a nascente doutrina sobre o tema, Daniela Jacques, em sua dissertação de mestrado, ${ }^{73}$ examinou as modernas tendências na doutrina c na prática jurisprudencial, para ampliar o âmbito de aplicajáo da lei do foro, em especial nos casos versando sobre os consumidores. Demonstrou a inadequação do método conflitual para regular essas relações

- Assim é ciamado o novimento surgido na doutrina americana no século XX, e na sla jurisprudência pelo emblemático caso

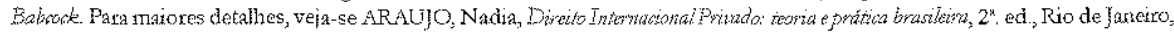

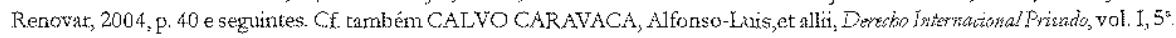
ed., Granacta, 2004, p. 218 e seguintes.

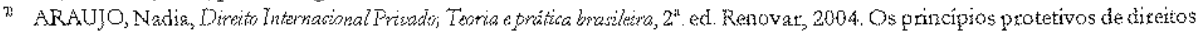
humanos inferferem na opetacionalização do método de soluçẫo de conflitos do $\operatorname{DIPr}$ ( $\mathrm{p}$. 16 e seguintes).

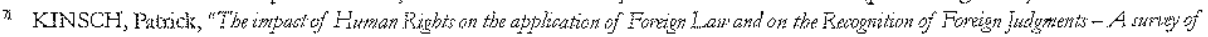

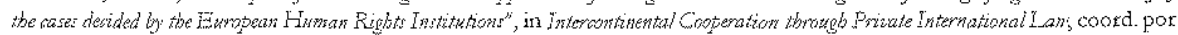
Talia Enhom e Kurt Siehr, The Fague, Asser Press, 2004, p. 196.

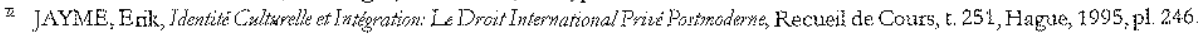

3 JACQUES, Op. Cit, 
jurídicas e propôs o estudo das nomas de aplicação imediata como método autônomo do direito internacional privado, no contexto de pluralismo de métodos defendido pelos autores contemporâneos, com análise profunda do caso Panasonic, julgado pelo STJ ${ }^{74}$ Entretanto, critica a possibilidade de um territorialismo exacerbado com a utilização demasiada desse tipo de norma, pois sua aplicação sempre terá como ponto de partida os valores do foro.

Voltando à proposta de Claudia Lima Marques, o artigo $5^{\circ}$ cuida das exclusões, técnica sempre utilizada em outros documentos internacionais, como a Convenção do México, com a qual guarda harmonia, a Convenção de Roma e a Convenção de Compra e Venda Intemacional dá Uncitral.

Os artigos $6^{\circ}$ e $7^{\circ}$ tratam de duas situações específicas: o consumidor-turista e os casos de multipropriedade, modalidade de direito real pouco utilizada entre nós, mas conhecida de brasileiros que viajam ao exterior e se entusiasmam com as vantagens oferecidas em situações excepcionais, sem se datem conta das conseqüências para o futuro. O primeiro foi inspirado na Lei Alemã sobre pacotes turísticos, no $\$ 41$ da lei austríaca, nos ensinamentos da doutrina européia e nos exemplos da jurisprudência nacional. Com relação aos contratos de time-sharing, inspirou-se em dispositivos existentes na Europa e na lei paraguaia, ${ }^{75}$ além da jurisprudência brasileira. Há, inclusive, diversas situações desse tipo no Mercosul, pois o mercado imobiliário de Punta del Este trabalha com esse sistema.

\section{CONCLUSÃO}

Existe uma enorme diferença entre as características dos contratos internacionais realizados entre comerciantes e profissionais e os celebrados com una parte mais fraca, o consumidor. É preciso criar regras que garantam um sistema de proteção ao consumidor no âmbito do intemacional nas Américas e no Mercosul, pois as regras existentes são insuficientes.

A proposta de Claudia Lima Marques, apresentada pelo Brasil como sugestão à agenda da CIDIP VII, é a mais adequada para dar uma solução à situação atual dos consumidores nas Américas, que se mostra no momento insatisfatória. Servirá também para os países do Mercosul, sempre ativos colaboradores nas CIDIPs, evitando-se uma superposição de regras para um grupo pequeno e outra para um grupo maior. Um de seus pontos fortes é garantir ao consumidor a possibilidade de escolher a lei aplicável, ainda que dentro de certos limites, o que demonstra sua preocupação com a proteção da parte mais fraca, sem no entanto retirar-lhe a liberdade de escolher.

7 JACQUES, op., cit.. Tranbém identificou a auto ra os pontos crítcos quanto ao uso excessivo do novo inétodo, que implicaria lim nacionalisno exacedado e un afastamento dos prinćpios classicos to direito intemacional privado. Por isso, procurou conjugar algurs aspectos do método conllitual, anda considerados fundamentais pela dontrina, e apresentar propostas de superação do unilateralisıno das no rmas de aplicação imediata, com a elabo tação de nomas conflituás de caráter substancial e a adoçâo de convençồes intemacionais.

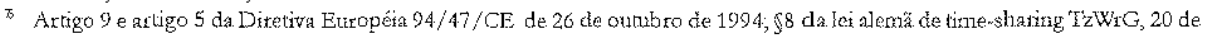
dezenbro de 1996, agora incorporida a BGB ena Anzérica do Sul, artigo 15 da Lei unuguai, Ley 17.189/99, e artigo 2 da lei paraguaia, Ley $1334 / 98$. 
Quando tivermos uma convenção sobre a lei aplicável aos contratos internacionais com os consumidores, a questão da lei aplicável estará regulada distintamente para os contratos $B 2 B$ e $B 2 C$, facilitando as trocas intemacionais e promovendo incremento no comércio regional. Desta forma, o sistema estará completo com as duas convenç̧ões sobre contratos internacionais: a Convenção do México, culja promoção para adoção em um maior númeto de países é necessária, e a da presente proposta.

A resposta à pergunta formulada por Claudia Lima Marques - sobre a adequação do nosso ordenamento jurídico para a intemacionalização das relações de consumo -, é positiva, agora que seu projeto transformou-se em uma proposta concreta do Brasil à agenda da CIDIP VII.

\section{Bibliografia}

ARAUJO, Nadia, Contratos Internacionais, 3. ed., Rio de Janeiro, Renovar, 2004. . Código do Mefrosul, Rio de Janeiro, Renovar, 1998.

- MAIRQUES, Frederico Magalhães e REIS, Márcio, Código do Mercosul- Tratados e Legislação, Ed. Renovar, Rio de Janeiro, 1998.

2004.

Direito Internacional Privado: teoria o pratica brasileira, $2^{2}$. ed., Rio de Janeiro, Renovar,

ARROYO, Diego P. Fernandez(coord) Derecho Internacional Privado de los Estados do Mercosur, Buenos Aires, Zavalia, 2003.

The Present and the future of Cidit, disponivel em www.oas.org.

BELANDRO, Rubens, El derecho aplicable a los contratos internacionales, Montevidéu, FCU, 1996.

CALVO CARAVACA, Alfonso-Luiz e GANDARA, Luiz Fernandez, Contratos Internacionales, Madrid, Tecnos, 1997.

, e GONZALEZ, Javier Carrascosa, (diretores) Derecho Internacional Privado, vol. II, $5^{2}$. ed., Granada, Ed. Comares, 2004.

CARPENA, Helósa a Abuso do Direito nos contratos de consumo, Rio de Janeiro, Renovar, 2001. CASELLA, Paulo Borba; "Utilização no Brasil dos Princípios UNIDROIT relativos aos contratos comerciais internacionais" in Contratos internacionais e direito econômico no Mercosul; Casella, Paulo Borba - Coordenador; São Paulo; 1996.

, e ARAUJO, Nadia, (coord) Integração Jurídica Interamericana, São Paulo, LTr, 1998.

DOLINGER, Jacob, "O Direito Internacional e sua aplicação pelo direito brasileiro: atualidades e perspectivas do Direito Intemacional Privado", in O Direito Internacional e o Direito Brasileiro, org. Wagner Meneses, Ijuí, Ed. Unijuí, 2004.

, TIBÚRCIO, CARMEN, Vademécum de Direito Internacional Privado, $2^{2}$. ed., Rio de Janeiro, Renovar.

FRESNERO DE AGUIRE, Cecília, "I as Clausulas abusivas y la dáusula de junisdiccion en los contratas internacionales de adhesion", in Rerista Judicatura, Montevideu, n. 34, p. 273/298. HERNÁNDEZ-BRETÓN, IPRAX 1998. 
JACQUES, Daniela, "Direito Internacional Privado e Direito do Consumidor: Adequacião dos métodos de DIPr para a proteção do consumidor", defendida em janeiro de 2004, e no prelo, na RT, na Biblioteca de Direito do Consumidor.

JAYME, Erik, Identité Culturelle et Intégration: Le Droit International Privé Postmoderne, Recueil de Cours, t. 251, Hague, 1995.

JUENGER, Friedrich, "Contract Choice of Law in the Americas" in American Joumal of Comparative Lam, vol. 45, 1997

"La Convencion Europea sobre el derecho aplicable a obligaciones contratuales: algunas observaciones ctiticas desde la perspectiva estaduinidense, in Juridica, n. 14, 1982, p. 201.

KASSIS, Antoine, Le nourean droit europién de contrats internationatix, Paris, LGDJ, 1993.

KINSCH, Patrick, "The impact of Humon Rigbts on the application of Foreign Law and on the Recognition of Foreign Judgments - A survey of the cases decided by the European Human Rights Institutions", in Intercontinental Cooperation through Private International Law, coord. por "Talia Einhorn e Kurt Siehr, The Hague, Asser Press, 2004.

KJAUSSNER, Eduardo Antonio, Direitos do Consumidor no Merosul e na União Européta, Curitiba, Juruá, 2006.

LECLERC, Fréderic, La protection de la partie faible dans le contrats internationaux, Btuylant, Bruxelas, 1995.

MARQUES, Cláudia Lima, Confiança no Comérico Eletrônico e a Proteção do Consumidor, São Paulo, RT, 2004.

, "Mercosul como Legislador em mativia de direito do consumidor - vrítica ao projeto de Protocolo de Defesa do Consumidor", in Renista de Direito do Consumidor, n. 26, 1998.

"Contratos no Código de Defesa do Consumidor", 44. edição, São Paulo, RT, 2002

Curso de Direito Internacional XXVII, 2001, OEA, p. 657/780.

"A protejão do consumidor: aspectos de direito privado regional e geral", in XXVII Curso de Derecho Internacional 2000, Secretaria General, OEA, Washington, 2001, p. 657/780.

- "Por um Direito Internacional de Proteção dos Consumidores: sugestões para a nova Lei de Introduşão ao Código Civil Brasileino no que se refere à lei aplicável a alguns contratos e acidentes de consumo", in O Direito Internacional e o Direito Brasileiro - Homenagem a José Francisco Resee, Wagner: Meneses, org, Ed. Unijuí, ljuí, 2004, p. 691/692.

"Confianja no Comérizo Eletrônico e a Protęano do Consumidor", São Paulo, RT, 2004.

MARQUES DOS SANTOS, Antonio, As normar de aplicaräo imediata no Direito Internacional Privado, vol. 1 e II, Coimbra, Almedina, 1991.

MARTINS, Ana Maria Guerra, Curso de Direito Constitucional da União Européia, Coimbra, Almedina, 2004.

MAYER, Pierre, "Laprotection de lapartie faible em Droit International Prive", in La protection de la partie Faible dans les rapports contractuels, L_GDJ, Paris, 1996.

MULFOLLAND, Caithin, Internete Contratação, Rio de Janeiro, Renovar, 2006.

NORTH, Peter, "Private International Law problems in common law junisdictions", London, Martinus Nijhoff, 1992. 
OPPERTI-BADAN, Didier, e FRESNERODE AGUIRRE, Cecília, "Contratos Comeriales Intemacionales", Montevidétu, FCU, 1997.

POMMIER, Jean-Cris tophe, "Principe d'autonomie de loi du contrat en Droit International Prite", Paris, Economica, 1992.

RIGAUX, François, "Droit International Privé", tome II, Bruxelas, Maison Larcier, 1993. SOUZA Jr., Lauro da Garna, "Os Principios do Unidroit relatizos aas contratos comerciais internacionais e sua aplicação nos paises do Mercosul" in Contratos Internacionais, coord. João Grandino Rodas, $3^{\text {a. }}$ ed., São Paulo, RT, 2002.

"TONIOLLO, Javier Alberto, "Laprotecion internacional del consumidor", in Revista Del Derecho Del Mercosur, n. 6, 1998, pp. 94/117.

"Reflexiones acerca del Derecho Internacional Privado Latinoamericano; Especial referencia al ambito del Meriosur", in Avances del Derecho Internacional Privado en America Latina, Liber Amicorum Jürgen Samtleben, Montevideu, FCU, 2002.

VASQUEZ, Carlos Manucl e RODAS, João Grandino Cidip VII and Beyond, disponível em wwwoas.org. 